Tropical Agricultural Pesearch \& Extension 20 (1 \& 2): 2017

\title{
EFFECT OF STORING TIME AND TEMPERATURE ON MILLING QUALITY OF PAR- BOILED AND RAW RICE OF AN IMPROVED IVARIETY, AT 362 AND A TRADITIONAL VARIETY, KURULUTHUDA
}

\author{
MGG Awanthi $^{1 *}$, SB Navaratne ${ }^{2}$, BMS Jinendra $^{1}$ and CM Navaratne ${ }^{1}$ \\ ${ }^{1}$ Department of Agricultural Engineering, Faculty of Agriculture, University of Ruhuna \\ ${ }^{2}$ Department of Food Science and Technology, Faculty of Applied Science, University of Jayawardhanapura
}

\begin{abstract}
Future rises in global surface temperature threaten for rice dependent nations. Previous research has failed to account for the detrimental impact of high temperatures on milling quality in paddy storing. Therefore, main objectives of this study were to assess the milling quality of paddy stored at different temperatures in line with global warming and to identify adaptation techniques. Experiment was conducted as a split-split plot design with 3 replicates. Main, sub and sub-sub plot factors were variety (AT-362, Kuruluthuda), processing technique (raw, parboiled) and storage temperature $\left(26,30,34,38^{\circ} \mathrm{C}\right)$ respectively. Head Rice Yield (HRY), Broken Rice Yield (BRY) and Degree of Milling (DOM) were estimated initially and after 6 months. Result revealed that HRY of paddy decreased by the range of $2.1-3.5 \%$ with increase in storage temperature from $26^{\circ} \mathrm{C}$ to $38^{\circ} \mathrm{C}$ after 6 months. However, temperature was not significantly influenced on HRY and BRY of stored paddy (P>0.05). The DOM was significantly lower $(2.07 \%)$ at $38^{\circ} \mathrm{C}$ than other temperatures. The HRY is significantly higher $(\mathrm{P}<0.05)$ in parboiled rice than raw rice in both varieties after 6 month at each temperature level. It can be concluded that milling quality of stored paddy is degrading at high temperatures yielding high amount of broken rice and low head rice, Furthermore, Kuruluthuda variety stored at comparatively high temperatures seems to be more tolerant to breakage during the milling compared with AT-362.
\end{abstract}

Key words: Temperature, Milling Quality, Paddy, Storage, Head rice, Broken rice

\section{INTRODUCTION}

Global warming has become a serious challenge in the world today. Increasing temperature is the major culprit and most obvious effect of global warming. Under the predictions of high greenhouse gas emissions scenario, called RCP (Representative Concentration Pathways) 8.5 , global mean surface temperature will be increased 2.6 to $4.8^{\circ} \mathrm{C}$ from the year 2081 to 2100 (Pachauri and Meyer, 2014). Besides changes to the physical conditions of the planet, global warming and climate change will have deleterious potential on the crop yields and quality parameters (Deschenes and Greenstone, 2012). Peng et al., (2004) reported that $1{ }^{\circ} \mathrm{C}$ increase of daily maximum and minimum temperature lead to decline the paddy yield by $10 \%$. Paddy is cultivated in over 100 countries in the world and more than $90 \%$ of

*Corresponding author: mggawanthi@gmail.com the world's rice production is in tropical countries in Asia (Khush, 2005). Prevailing maximum temperature during day time in tropical rice-producing countries is around $35^{\circ} \mathrm{C}$ (Noomhorm, Yubai, 1991). However, in accordance with global warming predictions, the ambient air temperature in rice production areas can be raised more than $35^{\circ} \mathrm{C}$ within next 100 years. The remarkable environmental temperature increment can adversely affect not only the rice yield but also the rice quality through altering the distribution of head and broken rice during the milling process (Lyman et al., 2013; Noomhorm and Yubai, 1991).

Milling quality can be introduced as a foremost determinant of the grain quality because it ultimately determines edible rice yield and its market value. Percent HRY is mainly used to evaluate milling quality due to high com- 
mercial demand for whole kernels (Noomhorm and Yubai, 1991). Numerous factors affect the breakage of rice kernel during milling including kernel temperature and moisture content, environmental milling conditions (Temperature and Relative humidity) and the operating conditions of the milling machinery (Luh, 1980). Among these conditions, environmental conditions particularly temperature have a significant effect on the milling quality. Temperature affects various milling quality characteristics of the paddy kernel such as chalkiness, immature kernels, kernel dimensions, fissuring, protein content, amylose content and length of amylopectin chain (Wassmann et al., 2009). Decreasing HRY and increasing BRY are the adverse effect of high temperatures in terms of milling quality (Lyman et al., 2013).

Most of the research seems to indicate that environmental conditions exerted before harvesting have a significant effect on the rice milling quality. However, it was failed to account for the detrimental impact of high temperature on milling quality during different post-harvest activities. Besides conditions during harvesting and drying, storage and other pre-milling operations are found to be primarily influenced on rice milling quality (Noomhorm and Yubai, 1991). Sri Lankan paddy farmers store around $50 \%$ of the harvested paddy for consumption, seeds and future sale under the fluctuation of market price for a period of 6-12 months (Hafeel et al., 2008). Therefore, storing paddy for a long time is an enormous requirement. Furthermore, average ambient storage temperature used for commercial storage of paddy and other grains in Sri Lanka is $30 \pm 2{ }^{\circ} \mathrm{C}$ (Prasantha, 2014). Estimated on-farm storage loss is about $8 \%$ (approximately 4 million metric tons) (Adhikarinayake et al., 2006). Therefore, the main objective of this study was to assess the milling quality of paddy stored at different temperatures in line with global warming and to identify adaptation technique to reduce the losses in milling process.

\section{MATERIALS AND METHOD}

\section{Sample preparation}

AT-362 (an improved rice variety) and Kuruluthuda (a traditional rice variety) certified by Department of Agriculture, Gonnoruwa, Sri Lanka were collected from a batch of freshly harvested paddy in 2016/17 Maha season at Mapalana, Kamburupitiya southern province, Sri Lanka. After cleaning, paddy was sun dried until it reach $14 \%$ of moisture content. About $120 \mathrm{~kg}$ of each rice variety was divided into two portions and one portion of each was parboiled by adapting following processing steps. Firstly, two portions of each variety were soaked in cold water for $48 \mathrm{hr}$ while replacing water with fresh in every $12 \mathrm{hr}$ to get rid of the development of microbes which impart foul smell for the parboiled rice. The soaked water was drained off and steamed for about 4 to $6 \mathrm{~min}$ until few grains were split open over the surface of the paddy. The parboiled paddy was dried in an open sun drying yard as a thin layer (Thickness approximately $1 \mathrm{~cm}$ ) until moisture content reaches to $18 \%$. Thereafter, these paddy were heaped up and kept for 2-3h for uniform moisture diffusion with a view to prevent the case-hardening of the grains. Finally, paddy was spread over the sun drying yard again to get the final moisture content for $14 \%$. Thereafter, $5 \mathrm{~kg}$ of parboiled and raw paddy of each variety were packed in poly sacks $(0.45 \mathrm{~m} \mathrm{x}$ $0.3 \mathrm{~m})$.

\section{Storing Paddy}

Four wooden chambers were fabricated for 4 temperatures as storage structures under controlled conditions of temperature. The most appropriate distances to keep paddy bags in the chambers were observed by changing the distances of upper most shelfs and making holes in bottom shelf. Dimensions of a chamber are given in Fig 1. These chambers were equipped with an electrical heat energy source along with an Arduino micro controller system and DHT 11(Distributed temperature sensing) temperature and relative humidity sensors to maintain the stipulated temperature uniformly as well as to record the temperature and relative 
humidity inside the chambers. Packed paddy were stored under 4 different temperatures namely $26,30,34$ and $38^{\circ} \mathrm{C}$ and Relative humidity level were found $75 \pm 5 \%, 65 \pm 5 \%$, $55 \pm 5 \%$ and $45 \pm 5 \%$ respectively for 6 months. Generally, parboiled paddy are not stored and milled after drying. However, in this study dried parboiled paddy was stored for 6 months only for detecting the quality changes during storage period.

\section{Experimental design}

The study was conducted according to splitsplit plot design, while replicating all treatments in triplicate levels. The variety is the main plot factor with 2 levels (AT-362, Kuruluthuda), processing technique is the sub plot factor with 2 levels (raw, parboiled) and temperature is the sub-sub plot factor with 4 levels $\left(26^{\circ} \mathrm{C}, 30^{\circ} \mathrm{C}, 34^{\circ} \mathrm{C}\right.$ and $\left.38^{\circ} \mathrm{C}\right)$.

\section{Data Collection}

The milling quality tests of rough rice samples were evaluated in terms of HRY and BRY and DOM. For each test $200 \mathrm{~g}$ of paddy samples were drawn after 6 months and passed through a laboratory huller, (Model

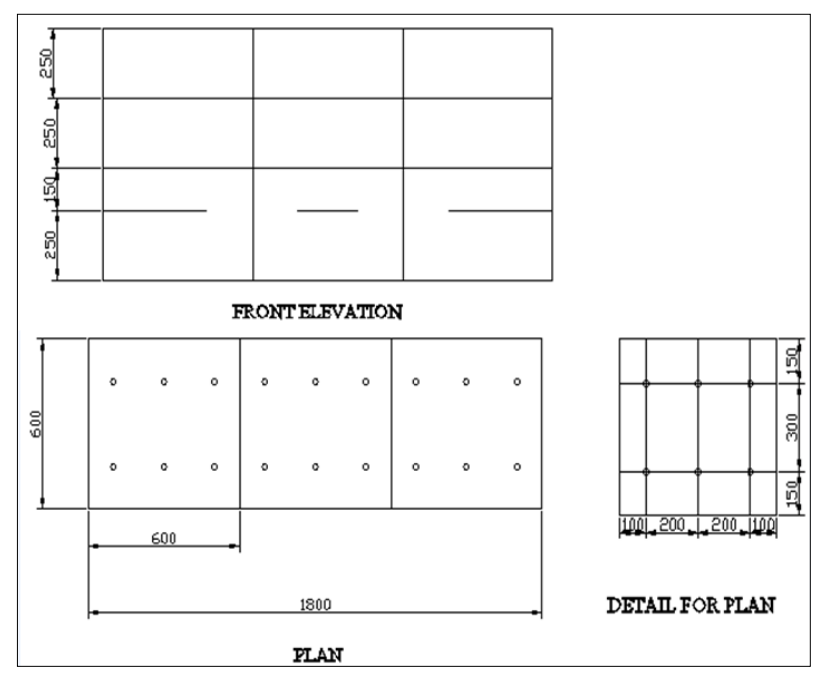

Figure 1: Dimensions of a fabricated storage chamber in different views in $\mathrm{mm}$. The chamber was divided in to 3 sub cahambers for replications and 4 bags were stored in a replicate shelf.
THU-35B Zatake) for two times. The resulting brown rice were poured into the laboratory polishing machine (Model TM-050) for 12 seconds. Milled rice sample was mixed and divided using sample divider for four times. Nearly $1 / 5^{\text {th }}$ of the milled rice sample were used to determine the weight of whole grains and broken grains as a representing unit. Separation of head rice from the broken was carried out manually. The HRY consists of rice kernels of three-quarters the size of whole kernels or larger. Weights of the paddy, brown rice, milled rice, broken rice and head rice were recorded in every sample. Thereafter, HRY and BRY and DOM were measured for each treatment according to the equations 1,2 and 3 (Wimberly, 1983).

Percent HRY $=\frac{\text { Weight of whole grains }}{\text { Weight of paddy sample }} \times 100$

Percent BRY $=\frac{\text { Weight of broken grains }}{\text { Weight of paddy sample }} \times 100$ (2)

Percent DOM $=\frac{\text { Weight of brown rice }- \text { Weight of milled rice }}{\text { Weight of brown rice }} \times 100$

\section{Data Analysis}

All the analysis were performed in triplicates using SAS software package. Statistical significance of the data obtained from the study were analysed by three way analysing of the variance (ANOVA) using the PROC GLM procedure to understand the main and interaction effect of factors. Means were separated using Duncan multiple range test at $\mathrm{P}<0.05$ probability level.

\section{RESULTS AND DISCUSSION}

\section{Effect of storage temperature on HRY and} BRY of stored paddy after 6 months.

Temperature was not significantly affected on HRY after 6 months of storage period $\left(F_{1,24}=3.00, P>0.05\right)$. It was observed that HRY slightly decreased and BRY increased with increment of storage temperature in both rice varieties when milled as raw rice (Table 
1). The HRY of raw At-362 and Kuruluthuda decreased by $2.65 \%$ and $3.29 \%$ while HRY of parboiled At-362 and Kuruluthuda decreased by $3.49 \%$ and $2.11 \%$ with increase in storage temperature from $26^{\circ} \mathrm{C}$ to $38^{\circ} \mathrm{C}$ after 6 months.

Houston et al. (1957) indicated that total or HRY were not change significantly at temperature $21^{\circ} \mathrm{C}, 32^{\circ} \mathrm{C}$ and $35^{\circ} \mathrm{C}$. Our findings appear to be well supported by Noomhorm and Yubai (1991) who disclosed

Table 1: Changes in head rice yield and broken rice yield of AT-362 and Kuruluthuda paddy varieties in raw and parboiled form stored at different temperatures for 6 months (HRY; $n=48$,

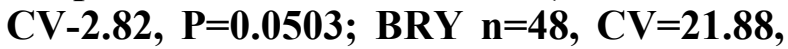
$\mathrm{P}=\mathbf{0 . 2 5 6 6 )}$

\begin{tabular}{|c|c|c|c|}
\hline $\begin{array}{c}\text { Processing } \\
\text { technique \& } \\
\text { Variety }\end{array}$ & $\begin{array}{c}\text { Storage } \\
\text { Temperature } \\
\left({ }^{\circ} \mathrm{C}\right)\end{array}$ & $\begin{array}{l}\text { Head Rice } \\
\text { Yield }(\%)\end{array}$ & $\begin{array}{l}\text { Broken } \\
\text { Rice } \\
\text { Yield (\%) }\end{array}$ \\
\hline \multirow[t]{4}{*}{ Raw AT-362 } & 26 & $57.31 \pm 0.51$ & $\begin{array}{l}12.96 \pm \\
2.86\end{array}$ \\
\hline & 30 & $56.95 \pm 0.71$ & $\begin{array}{l}13.86 \pm \\
0.62\end{array}$ \\
\hline & 34 & $56.03 \pm 1.38$ & $\begin{array}{l}14.09 \pm \\
1.62\end{array}$ \\
\hline & 38 & $55.79 \pm 0.45$ & $\begin{array}{l}15.08 \pm \\
3.97 \\
\end{array}$ \\
\hline \multirow[t]{4}{*}{$\begin{array}{l}\text { Parboiled } \\
\text { AT-362 }\end{array}$} & 26 & $62.91 \pm 0.98$ & $\begin{array}{l}7.98 \pm \\
0.93\end{array}$ \\
\hline & 30 & $61.55 \pm 1.04$ & $\begin{array}{l}8.38 \pm \\
2.40\end{array}$ \\
\hline & 34 & $60.64 \pm 1.48$ & $\begin{array}{l}9.35 \pm \\
0.63\end{array}$ \\
\hline & 38 & $60.71 \pm 2.34$ & $\begin{array}{l}10.36 \pm \\
0.33\end{array}$ \\
\hline \multirow[t]{4}{*}{$\begin{array}{l}\text { Raw } \\
\text { Kuruluthuda }\end{array}$} & 26 & $62.24 \pm 2.28$ & $\begin{array}{l}5.62 \pm \\
2.33\end{array}$ \\
\hline & 30 & $61.01 \pm 1.30$ & $\begin{array}{l}5.72 \pm \\
0.63\end{array}$ \\
\hline & 34 & $60.52 \pm 3.82$ & $\begin{array}{l}5.79 \pm \\
0.37\end{array}$ \\
\hline & 38 & $60.19 \pm 1.18$ & $\begin{array}{l}6.07 \pm \\
0.21\end{array}$ \\
\hline \multirow[t]{4}{*}{$\begin{array}{l}\text { Parboiled } \\
\text { Kuruluthuda }\end{array}$} & 26 & $69.53 \pm 0.34$ & $\begin{array}{l}2.26 \pm \\
0.11\end{array}$ \\
\hline & 30 & $68.15 \pm 1.55$ & $\begin{array}{l}3.08 \pm \\
0.69\end{array}$ \\
\hline & 34 & $67.28 \pm 2.79$ & $\begin{array}{l}3.28 \pm \\
0.85\end{array}$ \\
\hline & 38 & $68.09 \pm 0.74$ & $\begin{array}{l}2.85 \pm \\
0.80\end{array}$ \\
\hline
\end{tabular}

that HRY decreased by approximately $3.51 \%$, 1.26 and $1.65 \%$ with increase in temperature of the milling environment from 20 to $35^{\circ} \mathrm{C}$ at $40 \%, 60 \%$ and $80 \%$ RH levels. It was due to exerting high temperature stress in the kernel and creating fissures or cracks. It was found that HRYs of Wells rice cultivar stored at $35^{\circ} \mathrm{C}$ were significantly higher than those stored at 4 and $21^{\circ} \mathrm{C}$ (Pereira et al., 2008). Additionally, increasing storage temperature up to $37^{\circ} \mathrm{C}$ enhanced the aging of the stored paddy (Pearce and Marks, 2001) which leads to increase hardness of the starch granules and limited the granule hydration and swelling due to starch protein interaction (Tulyathan and Leeharatanaluk, 2007). Therefore, HRY may increase with increase in temperature. These negative and positive impact of high temperature on HRY and BRY may be due to different kernel structure of different paddy cultivars. Jang et al. (2009) claimed that although HRY decreased with storage temperature for Chucheongbyeo and Nampyeongbyeo cultivars, there were not any changes in Ilpumbyeo and Hwayeongbyeo cultivars.

Two factors interaction (variety*processing technique) was significant in terms of HRY after 6 months of storage period $\left(\mathrm{F}_{1,24}=5.38\right.$, $\mathrm{P}<0.05)$. Similar interaction was significant $\left(\mathrm{F}_{1,24}=4.38, \mathrm{P}<0.05\right)$ regarding $\mathrm{BRY}$ during the same storage period. Kuruluthuda variety showed significantly greater $(\mathrm{P}<0.05) \mathrm{HRY}$ and lower BRY than At-362 in both raw and parboiled form (Fig 2). Furthermore, HRY was significantly higher while BRY was significantly lower in parboiled paddy compared with raw paddy in both varieties. It was due to changes occur during heating up step in parboiling process. Deycke et al. (2005) highlighted the three important changes occur during parboiling result in high HRY. The changes are starch gelatinization, complexation of rice lipids with amylose fraction and formation of disulphide bonds between components of the rice protein fraction. 


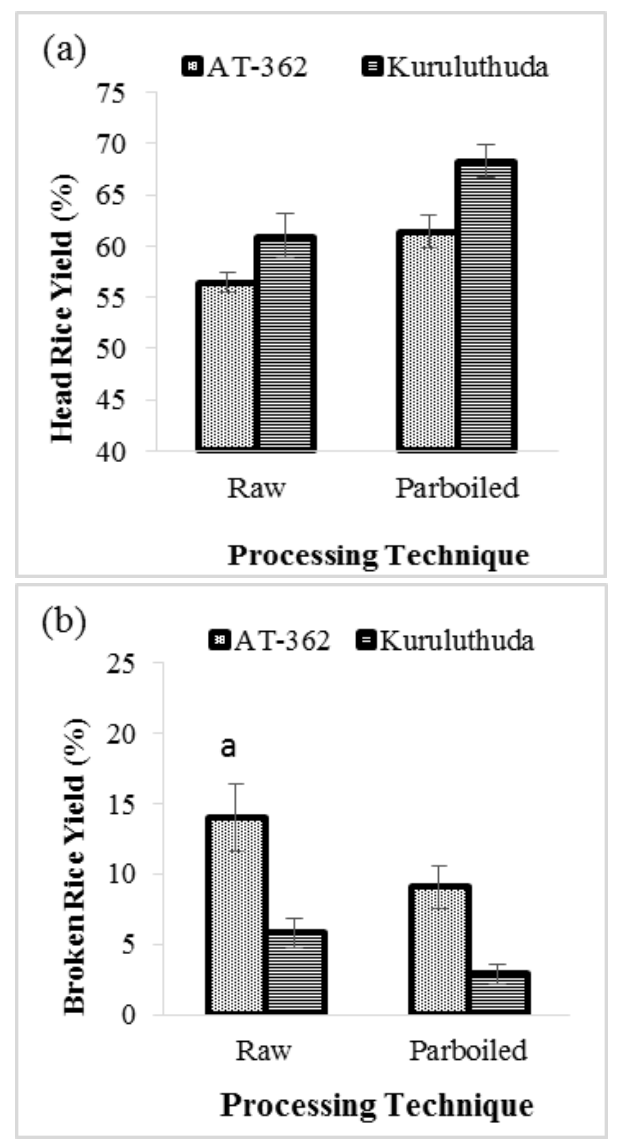

Figure 2: Head rice yield (a) and broken rice yield (b) of rice varieties, kuruluthuda and At 362 after 6-month storage as par-boiled and raw rice. Columns (Means) with the same letter are not significantly different at $5 \%$ level $(n=48)$.

\section{Effect of storage temperature on DOM of stored paddy after 6 months}

Based on statistical analyses pertaining to DOM, temperature found to be significant as a main factor $\left(\mathrm{F}_{3,24}=3.29, \mathrm{P}<0.05\right)$. Although most of the rice consumers prefer to eat rice with high DOM because of the better appearance and taste, nutritional losses are high in rice with high DOM. However, rice with low DOM has started gaining importance since its health benefits (Puri et al., 2014). Degree of milling was significantly lower $(2.07 \%)$ in paddy stored at $38^{\circ} \mathrm{C}$ than other storage temperatures. It implies that high temperature decrease the DOM of stored paddy after 6 months. It may be due to increasing the hardness of paddy with storage time before its ageing process (Pereira et al., 2008). Therefore, it was more difficult to remove the rice bran from the kernel during milling process. On the other hand, Archer and Siebenmorgen (1995) have explained that there was an effect of high temperature on DOM. According to their study, low DOM were obtained at low milling temperatures due to high viscosity of the oil in rice bran. Furthermore, Kanlayakrit and Maweang (2013) was found that rice bran was more susceptible to different reactions at high temperature than the endosperm of the rice kernel.

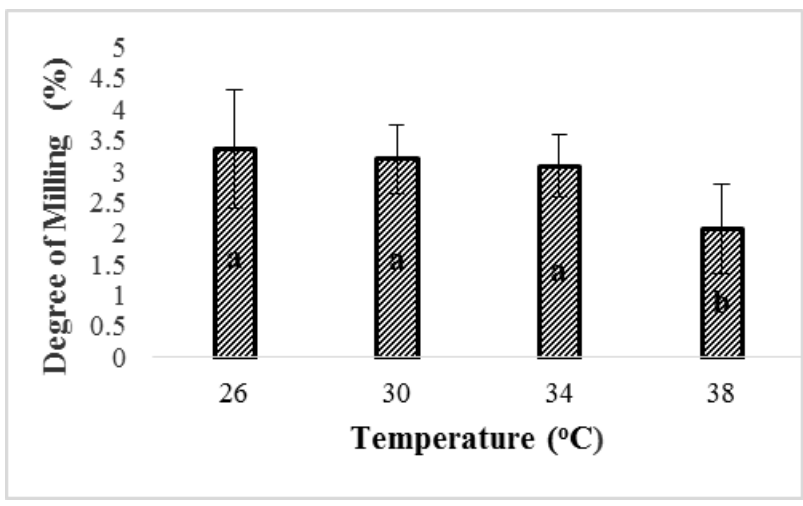

Figure 3: Degree of milling of paddy stored under different temperatures after 6-month storage. Columns (Means) with the same letter are not significantly different at $5 \%$

Effect of rice variety and processing technique on DOM of stored paddy after 6 months

Results revealed that (variety*processing) 2 factors interaction was significant affected on $\operatorname{DOM}\left(\mathrm{F}_{1,24}=19.84, \mathrm{P}<0.05\right)$. It was highlighted that DOM in parboiled rice was significantly lower than that of raw paddy (Fig 4). It is generally accepted that parboiling leads to increase in hardness of the grain resulting in reduced DOM (Gujral et al., 2002). The highest DOM was observed in raw AT-362 (5.36\%) and it was significantly higher than raw $\mathrm{Ku}-$ ruluthuda. It might be, as a result of the diverse varietal characteristics of paddy which plays vital role in milling quality (Patel, 2013). 
In the present study, Kuruluthuda variety shows high HRY, low BRY and low DOM even at high temperatures. Yadav and Jindal (2008) disclosed that high HRY is given by some paddy varieties which has a high amylose $(>20 \%)$ content, low alkali spreading value and high protein $(>7 \%)$. Kuruluthuda rice variety contains high protein, fibre, necessary fatty acids and lower glycemic index compared to other common rice varieties in Sri Lanka (Withanawasam, 2017). Additionally, Gelatinization temperature of Kuruluthuda was recorded as high compared to other traditional rice varieties (Rebeira, 2014). Therefore, further studies have to be carried out to determine the heat resistance behaviour of Kuruluthuda paddy.

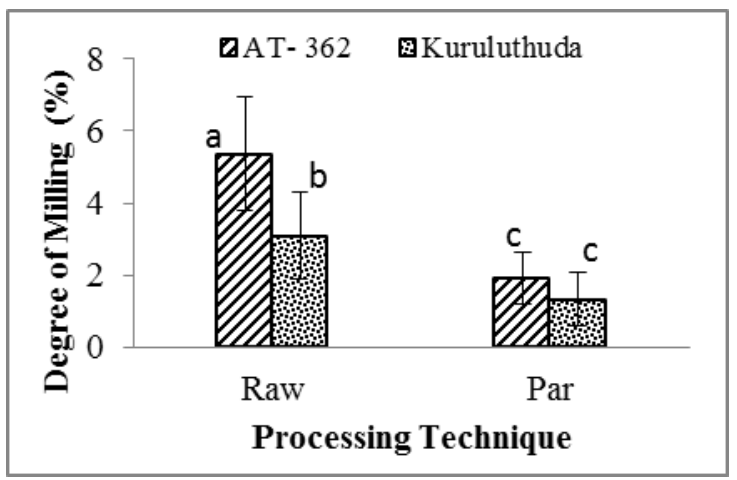

Figure 4: Head rice yield (a) and broken rice yield (b) of rice varieties, kuruluthuda and At 362 after 6-month storage as par-boiled and raw rice. Columns (Means) with the same letter are not significantly different at $5 \%$ level $(n=48)$.

\section{CONCLUSION}

The head rice yield, broken rice yield and degree of milling are the foremost determinant in terms of rice quality. It can be concluded that milling quality of stored paddy is degrading at high temperatures result in high broken rice yield, low head rice yield and low degree of milling. In addition, combination of variety and processing technology was significantly influenced on head rice yield and degree of milling of stored paddy after 6 months. Milling quality of parboiled paddy stored for 6 months was higher than raw paddy. Kuruluthuda rice variety shows higher head rice yield, lower broken rice yield and lower degree of milling even at high temperatures than At-362. According to its investigated features, Kuruluthuda shows a natural resistance to withstand at high temperatures during storage and further experiments needs to be conducted to explore it.

\section{REFERENCES}

Adhikarinayake TB, Palipane KB and Müller J 2006 Quality changes and mass loss of paddy during airtight storage in a ferro-cement bin in sri lanka. J. Stored Prod. Research. 42: 377390.

Archer TR and Siebenmorgen TJ 1995 Milling quality as affected by brown rice temperature. Cereal Chemistry. 72(3): 304-307.

Derycke V, Vandeputte GE, Vermeylen R, De Man W, Goderis B, Koch MHJ and Delcour JA 2005 Starch gelatinization and amyloselipid interactions during rice parboiling investigated by temperature resolved wide angle X-ray scattering and differential scanning calorimetry. Journal of Cereal Science. 42(3): 334-343.

Deschenes O and Greenstone M 2012 The economic impacts of climate change: evidence from agricultural output and random fluctuations in weather: reply. Am. Econ. Rev. 102: 3761-3773.

Gujral HS, Singh J, Sodhi NS and Singh N 2002 Effect of milling variables on the degree of milling of unparboiled and parboiled rice. International Journal of Food Properties. 5(1): 193-204.

Hafeel RF, Prasantha BDR and Dissanayake DMN 2008 Effect of hermetic-storage on milling characteristics of six different varieties of paddy. Tropical Agric. Research. 6: 102114.

Houston DF, Straka RP, Hunter IR, Roberts RL and Kester EB 1957 Changes in rough rice of different moisture content during storage at controlled temperatures. Cereal Chemistry. 34: 444-456.

Jang EH, Lim ST and Kim SS 2009 Effect of storage temperature for paddy on consumer 
perception of cooked rice. Cereal chemistry. 86(5): 549-555.

Khush GS 2005 What it will take to feed 5.0 billion rice consumers in 2030. Plant molecular biology. 59(1): 1-6.

Luh BS 1980 Rice: Production and Utilization. AVI Publishing, Westport, CT

Lyman NB, Jagadish KS, Nalley LL, Dixon BL and Siebenmorgen T 2013 Neglecting rice milling yield and quality underestimates economic losses from high-temperature stress. PloS one, 8(8): 72157.

Noomhorm A and Yubai C 1991 Effect of tropical environmental conditions on rice kernel breakage during milling. Journal of the Science of Food and Agriculture. 55(4): 521528.

Pachauri RK and Meyer L 2014 Climate change 2014 Synthesis Report-Summary for Policymakers.

Patel S 2013 Studies on test milling of some common varieties of summer paddy and kharif paddy grown in the state (Doctoral dissertation, Indira Gandhi Krishi Vishwavidyalaya, Raipur (CG)).

Pearce MD, Marks BP and Meullenet JF 2001 Effects of postharvest parameters on functional changes during rough rice storage. Cereal Chemistry. 78(3): 354-357.

Peng S, Huang J, Sheehy JE, Laza RC, Visperas RM, Zhong X, Centeno GS, Khush GS and Cassman KG 2004 Rice yields decline with higher night temperature from global warming. Proceedings of the National academy of Sciences of the United States of America. 101(27): 9971-9975.

Pereira T, Cooper N and Siebenmorgen T 2008 Effects of storage temperature and duration on the milling properties of rice. Discovery, The Student Journal of Dale Bumpers College of Agricultural, Food and Life Sciences. 9(1): 64-74.

Prasantha BR, Hafeel RF, Wimalasiri KMS and Pathirana UPD 2014 End-use quality characteristics of hermetically stored paddy. Journal of stored products research. 59: pp158 $-166$.

Puri S, Dhillon B and Sodhi NS 2014 Effect of degree of milling (Dom) on overall quality of
rice-A review. International Journal of Advanced Biotechnology and Research. 5(3): 474-489.

Rebeira SP, Wickramasinghe HAM, Samarasinghe WLG and Prashantha BDR 2014 Diversity of grain quality characteristics of traditional rice (Oryza sativa L.) varieties in Sri Lanka. Tropical Agricultural Research. 25 (4): $470-478$

Stathers T, Lamboll R and Mvumi BM 2013. Post harvest Agriculture in a changing climate. International Jornal of Rural Development. 47 (1): 12-14.

Tulyathan V and Leeharatanaluk B 2007 Changes in quality of rice (Oryza sativa L.) cv. Khao Dawk Mali 105 during storage. Journal of Food Biochemistry. 31: 415-425.

Wassmann R, Jagadish SVK, Heuer S, Ismail A and Redona E 2009 Climate change affecting rice production: the physiological and agronomic basis for possible adaptation strategies. Adv Agron. 101: 59-122.

Wimberly JE 1983 Technical handbook for the paddy rice postharvest industry in developing countries. Int. Rice Res. Inst. pp. 84-86.

Withanawasam DM 2017 Heritage of Heirloom Rice varieties of Sri Lanka, Regional Rice Research \& Development Centre. Department of Agriculture.

Yadav BK and Jindal VK 2008 Changes in head rice yield and whiteness during milling of rough rice (Oryza sativa L.). Journal of Food Engineering. 86: 113-121. 